\title{
Performance of Internet Finance Companies in China
}

\author{
Tian Zhongkaia, Ahmad Fahmi Sheikh Hassan
}

\begin{abstract}
Internet finance experienced fast development in the world including China. With around 2000 internet finance companies currently operating in China there is extensive competitions among internet finance companies offering financial services to investors. The paper empirically investigates the determinants of internet finance companies performance based on 330 randomly selected sample data using a linear regression method based on one-month information collected from an online internet finance database. The findings show that the interest rate level, number of projects, and average loan periods play a significant role in the performance of internet finance companies. This investigation could help internet finance companies to adopt effective competitive strategies in order to enhance market performance and at the same time help individual investors to identify good performed companies from the internet finance market.... The joint efforts from both internet finance companies and individual investors will promote the development of internet finance in China and accelerate the revolution of China traditional financial system.
\end{abstract}

Index Term: Internet finance, Firm performance, Operation information, China.

\section{INTRODUCTION}

With the advent of technology and competent software, today's trend of doing business and commerce is no longer restricted to the traditional method. The widespread use of mobile devices, the accessibility of instant information, the diversity of social media platforms and various other technological advancements have created an interconnected world. With multiple search engines, business people and the lay person have access to many things including loans. The latest development in computing and telecom technologies have changed the financial landscape for businesses. Current loan transactions do not require clients to formally come to the bank of financial institution, fill in forms, provide the necessary evidence and then wait for weeks for the loan processing to be done. Consequently, it has changed the way the financial industry operates.

Over the past decade more and more businesses have facilitated business transactions among individuals. Of the support provided to individuals, one of the most critical and innovative strategy to have emerged is internet finance. It is a type of financial assistance offered to the public via the internet or any IP network. Currently, it is closely observed

Revised Manuscript Received on 14 September, 2019.

Tian Zhongkai, PUTRA Business School, Universiti Putra Malaysia, 43400, Serdang, Selangor, Malaysia

Ahmad Fahmi Sheikh Hassan, Department of Accounting and Finance, Faculty of Economics and Management, Universiti Putra Malaysia by governments, industries, investors, and researchers (Cai, Lin, Xu, \& Fu, 2016; Dong, 2014; Moreira, 2016; Xu, 2017). Internet finance is a new and innovative method for making financial transactions. This method bypasses conventional financial intermediaries as it connects borrowers and lenders directly (Yum, Lee, \& Chae, 2012) thereby enhancing transactions and promoting commerce. Internet finance promotes transactions from peers to peers (P2P). The P2P form of lending or borrowing is considered one of the famous models of internet finance. In the internet environment, some websites run as platforms, providing financial services to lenders and borrowers. Through these websites, borrowers upload information to the website and lenders, based on the information of the borrowers and the platforms, make the decision on whether to lend money or not.

Internet loans or lending originated in the United Kingdom which also created the first P2P lending company called Zopa in 2005. Following this, was the United States which founded its first P2P internet lending company called Prosper in 2006. The Lending Club was then founded in 2007 and it is currently the largest P2P lending company in the USA. It accounts for approximately $80 \%$ of the P2P market share in the USA (Xu, 2017). However, the annual loan volume noted in 2014 was only several billion US dollars, despite being in existence for seven years. Nonetheless, in 2015, Lending Club issued US\$8 billion of loans, doubling that of 2014 and by December of the same year, it was public listed on the New York Stock Exchange (NYSE).

Meanwhile, the first internet finance platform that was established in China started in 2007. Since then, internet finance has increasingly acquired popularity and market recognition (Xinhua, 2017). Inspired by the internet lending platforms in the United States, the PPdai became China's first internet lending site in June 2007. This establishment was soon followed by other internet finance platforms such as Lufax, Hongling Capital, and Renrendai. The breakthrough innovations in information technology such as mobile communications, mobile payments, social networking, big data, and cloud computing since the launch of China's first internet lending platform in 2007 has enabled China's internet finance to flourish. In June 2013 there was an explosive development of the internet finance across the country as exemplified by Yu'e Bao. At the same time, other internet finance platforms also burst into the scene, for instance Alibaba and JD.com, the online financial supermarket of Lufax, and the 
P2P website represented by Renren Dai, and PP Dai, or the crowdfunding model of z.JD, and third party payments such as Alipay and Wechat pay.

With the internet industry in China fast developing, more and more internet companies are paying attention to the financial market. These internet companies are trying to enter the financial market and compete with conventional banks. The rapid growth of internet services in China has had a profound impact on the traditional financial industries, and financial technology companies have expanded their business scope, moving from online payment systems to financial services (Shim \& Shin, 2016). In recent years, internet finance has gradually transformed to become a cutting-edge system (Shim \& Shin, 2016). A large number of competitors are already engrossed with the internet finance market of China. To remain competitive, these platforms have to develop competitive strategies in order to encourage investors and cash flows. Hence, this study aims at examining the factors influencing the market performance of internet finance platforms in China.

The remainder of this study proceeds as follows. In section 2 , literatures related to internet finance and its contribution to SME financing in China are reviewed. Included in the section is the discussion on the theoretical framework used in the study and the hypothesis development. Section 3 presents the methodology of this study while the results are discussed in Section 4. The final section presents the conclusion and further implications brought from this study.

\section{LITERATURE REVIEW}

The fast development of the internet finance has attracted researchers' attention. However, most of the researchers had focused on one dominated website such as LendingClub and Prosper (Gonzalez \& McAleer, 2014; Serrano-Cinca, Gutierrez-Nieto, \& Lopez-Palacios, 2015; Traci L. Mach, 2014; Zott \& Amit, 2010). Other studies narrowly examined the relationship between internet finance platforms and conventional banks (Milne \& Parboteeah, 2016; Zhu \& Huang, 2014). In the context of China, the number of internet finance companies that exist today has overtaken that of the UK or the US market. Unlike the financial landscape of the UK and US where the internet finance market is dominated by large companies such as LendingClub and Prosper, the situation in China is slightly different. To date, China has around 2000 companies which offer internet finance in the market (Shih, 2018). These internet finance companies bring investment choices and financing channels to individual investors and Small and medium-sized enterprises (SMEs) borrowers.

SMEs are one of the many essential elements that help a country's economy to expand and grow. These enterprises are important; they offer business opportunities as well as provide employment (Ayyagari, Beck, \& Demirguc-Kunt, 2007; Burgstaller \& Wagner, 2015; D'Imperio, 2012) both of which can stimulate economic growth. . These SMEs remain to be the key factor driving competitiveness, growth, for European nations where large corporations had to innovation, and employment for many countries especially

downsize their workforce due to European sovereign debt crisis of 2011-2013(Moreira, 2016). Despite their contributions, SMEs face challenges in meeting their growth and expansion plans. For instance, SMEs find it difficult to access external financing supports, a general problem faced throughout the world (Burgstaller \& Wagner, 2015; Falkner \& Hiebl, 2015; Lavia López \& Hiebl, 2015). There are many reasons for this hindrance which will be further discussed below. The fact remains that without access to financial support, the financial situations of SMEs will be badly affected since they require external financing to support their investments, and this can hinder the economic development of the country (Ferrando \& Mulier, 2015; Prelipcean \& Boscoianu, 2014).

Even though the economy in China has been thriving in the past few years, its financial services are still lacking in many areas, one of which is that China's financial services are severely undersupplied (Xu, 2017). Undoubtedly, large companies, especially state-owned enterprises (SOEs) have no problems when it comes to financial support because these companies have access to a relatively adequate supply of external finances. Banks seem to think that these large companies are more reliable and trustworthy because their operations are more transparent hence making it easier, presumably, for lenders to identify the lending risks involved (Yin \& Liu, 2016). Conventional financial institutions usually prefer large companies and China's financial system is designed for large companies (Elliott \& Yan, 2013). Thus, this practice puts SMEs and micro-enterprises at a disadvantage; they would generally experience difficulties in accessing some inroads for external finances at a reasonable cost.

From the perspective of China, SMEs are gaining much importance particularly in the private sector. Its expansion in the market suggests that SMEs are becoming the main driver of China's economic growth (Lin, 2007). According to China Statistical Yearbook, SMEs account for $97.9 \%$ of the total number of enterprises in $2015^{\mathrm{i}}$. Their presence in the economic market is so valuable that it contributes to $58 \%$ of China's GDP, and Statistics also indicate that SMEs account for $68 \%$ of the imports and exports of the country ${ }^{\mathrm{ii}}$. Like other developing countries with SMEs, China also share similar challenges. For instance, its SMEs experienced lower penetration rates of financial services when compared to industrialized nations (Honohan \& King, 2009). Relevant to this, Jing (2014) reported that $89 \%$ of the SMEs in China have difficulties in fulfilling the requirements of banks in order to qualify for loans. This is traced to their problem with being able to provide adequate collaterals that banks require as a common practice of traditional Chinese banking models (Kshetri, 2016; Wildau, 2015). This impediment can be phenomenal in limiting the growth of SMEs and their contribution to world economy. As is realized, a country's economic growth is dependent on the exuberance of its industries. For an industry to be active, financial accessibility and affordability is necessary. 
Conventional loans and internet finance loans differ in a number of ways. While conventional loans are attached with numerous conditions, it appears that internet finance holds lesser restrictions. SMEs borrowers will benefit from internet finance and get financing support from internet finance companies. In the internet finance market, internet finance play the role like banks that absorb cash investment from individual investors. The internet finance platform lends money to those who need funds and then transfers the creditor's rights into small projects with different combination of interest rate and period for the individual investors. In this transfer process, internet finance platform can satisfy the needs for both borrowers and investors. Internet finance favours investors because the yields that individual investors gain are higher comparatively. Since the internet finance is operated via an online platform there is a lot of competition among internet finance platforms offering their financial services to investors and borrowers. In this regard, these internet finance platforms need to develop their own competitive strategies so as to be able to conduct their businesses. Then they need to strengthen their position as lenders through the support of the government since they are also helping the economy of the country to grow. Further to this, to encourage more investors and more cash flows, internet finance companies adopt competitive strategies based on interest rate, loan periods and number of projects. With internet finance becoming a trend in today's world, the healthy development of internet finance would benefit not just individuals but also the nation.

\section{A. Theoretical framework and hypothesis development}

The underlying theory used in this study is competitive strategy which refer to the positions companies take in trying to gain a competitive advantage over its competitors in the market (Porter, 1980, 1985). Through developing these competitive and strategic activities, companies aim to improve their consumer base and also increase their product or service quality. The company's competitive strategy is affected by the company's resources and capabilities. The more the resources, the stronger the company's ability to gain a competitive advantage. Applying the competitive strategies theory, the long term above-average performance of firms comes from two fundamental forms: low cost or differentiation (Porter, 1980, 1985). Lower cost would mean that companies gain more profits by selling their products or services at a lower cost than their competitors. However, a company's low-cost position may reduce the firm's ability to influence prices. Low interest rates on conventional bank savings motivated individuals to participate as investors in the internet finance market (Bruton, Khavul, Siegel, \& Wright, 2015). A large number of competitors are already engrossed with the internet finance market of China. The internet finance companies offer a high interest rates (Wahid \& Rehman, 2014). To remain competitive, some of these platforms offer very competitive interest rates which can fuel the competition even more. Without doubt, the interest rates provided by the internet finance companies have a direct influence on investors' yields. The interest rate is an important factor for investors when make investment decision. In the low cost strategy, when the internet finance company running with low-cost it can provide high interest rate for investors. The high interest rate can attract more investors and encourage more cash flows that will enhance the company performance. Hence, it is reasonable to hypothesize that:

H1: There is positive relationship between the interest rate offered for investors and the firm performance of internet finance companies in China.

Meanwhile, product differentiation strategy can be a competitive advantage tool adopted by organizations in order to provide products that satisfies individual investor's needs. Differentiation refers to the instance where a company takes a differentiated position to introduce more oligopoly (less competitive) but as before, this too may impact on firm prices (Ortega, 2010). In satisfying individual investor's needs, quality has become a major differentiating factor among products (Shammot, 2011). It is argued that product differentiation fulfills customers need and involves tailoring the product or service to the customer (Kavale, Mugambi, \& Namusonge, 2016). As a result, customers are willing to pay more for products that cater to their individual size, taste, style, need or expression. Hence, product differentiation is an important determining factor for achieving competitive advantage. In the internet finance environment, the differentiation strategies is made through the various investment choices provided for individual investors. Factors such as loan period and number of loan projects make difference between one internet finance platform to others. The first factor, i.e. loan periods, would test for investment periods preference of the investors (i.e. short-term vs. long-term period) while the second factor, i.e. the number of loan projects relate to the investment choices provided to investors. Therefore, our second and third hypotheses could be summarised as follow:

H2: There is a positive relationship between the loan periods for investors and the firm performance of internet finance companies in China;

H3: There is positive relationship between the number of loan projects and the firm performance of internet finance companies in China.

\section{Figure 1. Theoretical framework}

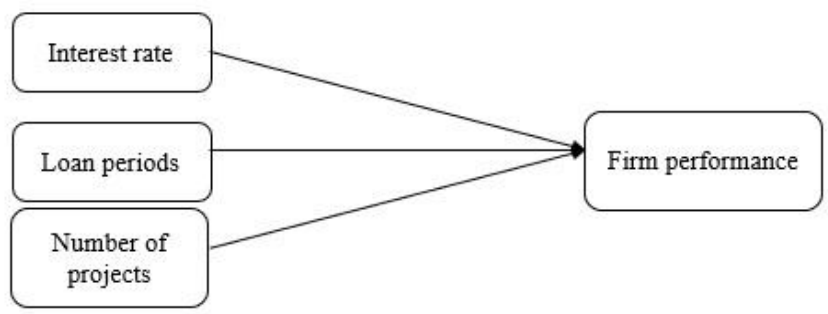

The figure 1 above is the theoretical framework. Based on the theoretical framework, the regression equation is illustrate below:
Blue Eyes Intelligence Engineering \& Sciences Publication 
Firm performance $=\mathrm{b} 0+\mathrm{b} 1 \mathrm{IR}+\mathrm{e}$

Firm performance $=\mathrm{b} 0+\mathrm{b} 1 \mathrm{LP}+\mathrm{e}$

Firm performance $=\mathrm{b} 0+\mathrm{b} 1 \mathrm{NP}+\mathrm{e}$

$\mathrm{IR}=$ Interest rate; $\mathrm{LP}=$ Loan periods; $\mathrm{NP}=$ Number of projects

\section{RESEARCH METHODOLOGY}

This study seeks to investigate how three factors, i.e. loan periods, the number of projects, and interest rates influence the performance of China internet finance companies. The performance of these companies are measured based on the number of investors and total transaction. Secondary data was used in this study where data was collected from a third-party website "wangdaizhijia" which provides information on internet finance platforms. At the end of December 2017 there are 1863 internet finance companies in China $^{\text {iii }}$. Due to constant daily changes of its number, this study used a sample investigation of internet finance companies at one point data acquired in July, 2018.

Meanwhile, the sample of this research is calculated by using Taro Yamane (Yamane, 1973) formula with 95\% confidence level. The calculation formula of Taro Yamane is presented as follows.

$$
\mathrm{n}=\frac{N}{1+N(e)^{2}}
$$

Where : $\mathrm{n}=$ sample size required

$\mathrm{N}=$ number of people in the population

$\mathrm{e}=$ allowable error $(\%)$

$$
\begin{aligned}
& \mathrm{n}=\frac{1863}{1+1868(\mathrm{~g} 0.05)^{2}} \\
& \mathrm{n}=329.30
\end{aligned}
$$

Following the Yamane calculation above the sample size of our study is rounded to 330 internet finance companies. Table 1 below summarizes the measurement of all variables

\begin{tabular}{|c|c|c|c|}
\hline Variables & Notations & Definition & $\begin{array}{l}\text { Data } \\
\text { Source }\end{array}$ \\
\hline $\begin{array}{l}\text { Total } \\
\text { Transactions }\end{array}$ & $\begin{array}{l}\text { Total } \\
\text { Transactions } \\
(10 \mathrm{k} \text { RMB) }\end{array}$ & $\begin{array}{l}\text { This is the } \\
\text { total } \\
\text { transaction } \\
\text { volume of an } \\
\text { internet } \\
\text { finance } \\
\text { company in a } \\
\text { month, } \\
\text { measured as } \\
10,000 \\
\text { Chinese Yuan } \\
\text { (RMB). }\end{array}$ & $\begin{array}{l}\text { Third-party } \\
\text { database }\end{array}$ \\
\hline $\begin{array}{l}\text { Number of } \\
\text { Investors }\end{array}$ & Investors & $\begin{array}{l}\text { This is the } \\
\text { total number } \\
\text { of investors } \\
\text { participate in } \\
\text { an internet } \\
\text { finance } \\
\text { company in a } \\
\text { month. }\end{array}$ & $\begin{array}{l}\text { Third-party } \\
\text { database }\end{array}$ \\
\hline
\end{tabular}
used in the study.

Table 1. Measurement of all variables
Interest Rate

Interest Rate

Loans periods

loan period

Loans periods for projects in Third-party (month)

Number of Projects Loan Projects an internet database finance company. The total number of loan projects issued by an internet Third-party finance company in a month.

Following prior studies, the dependent variables i.e. performance of internet finance companies are calculated using: total transactions (Bhagat, Carey, \& Elson, 1998) and number of customers (Ittner \& Larcker, 1998). In this study, individual investors are the main customers of the internet finance companies. Meanwhile, there are three independent variables used in this study: interest rates; loan periods and number of projects. The interest rate is measured as the interest rate offered to investors where significant changes in price and total transactions are observed (Michels, 2012). The high or low interest rate will directly influence the returns to investors. Meanwhile, Bodenhorn (2003) has applied loan periods as measures in lending market research calculated as the average loan period for projects in an internet finance companies. On the other hand, the number of projects reflect the investment choices provided by an internet finance company to individual investors. As asserted by Michels (2012), a large number of projects will generate large amount of transaction volumes.

Meanwhile, the data for this study was analyzed using exploratory data analysis (EDA) and SPSS linear regression. The EDA enables the basic characteristics of the research data to be exposed through descriptive statistics including sample means and the maximum, and minimum values. In addition, SPSS linear regression has been used to explore the linear relationship between independent variables and dependent variables. For this study the dependent variables are number of investors and total transaction while the independent variables are interest rates, average loan periods, and number of loan projects.

\section{RESULTS AND FINDINGS}

Table 2 below presents the descriptive statistics for the study. From the table, Total Transactions has a mean value of 39845.1699 with minimum and maximum values of 1602.74 and 1043081.35 respectively. This shows that the data point of the dependent variable is sparsely scattered 
around the mean suggesting high variability and variance. Meanwhile, Investors has a mean value of 13795.15 with minimum and maximum values of 10 and 664841 . On the other hand, Interest rate has a mean value of $10.51 \%$ with minimum and maximum values of $5.21 \%$ and $19.47 \%$ while the average loans periods has a mean value of 7.7052 with minimum and maximum of 0.29 and 39.32. As for the loan projects, the variable has a mean value of 143620.03 with minimum and maximum of 28 and 17,147,617 respectively. In summary, the descriptive statistics shows that data point of this variable is closely clustered around the mean implying that there is little variation and less error in the distribution of the data.

Table 2: Descriptive Statistics

\begin{tabular}{llll}
\hline Variables & $\begin{array}{l}\text { Minimu } \\
\text { m }\end{array}$ & $\begin{array}{l}\text { Maximu } \\
\text { m }\end{array}$ & Mean \\
\hline Total Transactions(10k & 1602.74 & $\begin{array}{l}1043081 \\
\text { RMB) }\end{array}$ & 39845.16 \\
Investors & 10 & 664841 & 13795.15 \\
Interest Rate (\%) & 5.21 & 19.47 & 10.5152 \\
Average Loans & .29 & 39.32 & 7.7052 \\
periods(month) & & 1714761 & 143620.0 \\
Loan Projects & 28 & 7 & 3 \\
\hline
\end{tabular}

Table 3 and 4 below present the regression results for our estimated model based on the two measures of firm performance: Total Transaction and the Number of Investors.

Table 3: Regression analysis results on Total Transaction

\begin{tabular}{lll}
\hline & $\begin{array}{l}\text { Standardized } \\
\text { Coefficients }(\boldsymbol{\beta})\end{array}$ \\
\hline Interest Rate (\%) & -.157 & .000 \\
Average Loans & .177 & .000 \\
periods(month) & .518 & .000 \\
Loan Projects & .00 \\
\hline
\end{tabular}

Dependent Variable: Total Transactions (10k RMB)

As evident in Table 3 above, the coefficients of the individual explanatory variables are all statistically significant at $5 \%$. The determinant interest rate $(\mathrm{H} 1)$ has a significant influence on Total Transactions with a negative effect on Total Transactions in China internet finance market. Meanwhile, the determinants of loan periods and the number of projects ( $\mathrm{H} 2$ and $\mathrm{H} 3)$ both have a positive and significant influence on Total Transactions. Therefore, it can be argued that loan period and the number of projects both have positively influence the performance of internet finance market in China. Meanwhile Table 4 below shows that the coefficients of the individual explanatory variables are all statistically significant at 5\%. For example, Interest rate $(\mathrm{H} 1)$ has a significant influence on number of investors. We argue that interest rate has a statistical significant negative effect on number of investors in China internet finance market. Meanwhile, both the loan periods (H2) and loan projects (H3) has a positive and significant influence on number of investors. Therefore, in the similar argument with Total Transaction earlier, we found that both loan periods and loan projects positively influence the performance of internet finance market in China.

Table 4: Regression analysis results on number of investors

\begin{tabular}{lll}
\hline & $\begin{array}{l}\text { Standardized } \\
\text { Coefficients }(\boldsymbol{\beta})\end{array}$ \\
\hline Interest Rate (\%) & -.101 & .001 \\
Average Loans & .170 & .000 \\
periods(month) & .772 & .000 \\
\hline Loan Projects & .00 \\
\hline
\end{tabular}

Dependent Variable: Investors

The results shown in the above is consistent with (Klafft, 2008) and uphold the argument brought forward in the competitive strategies theory. This indicates that the interest rate in internet finance market is a significant factor considered by investors. Previous studies also indicated that some investors in the internet finance market were unable to generate acceptable returns with their investments due to a high number of loan defaults (Kredite, 2007; Rose, 2007). On the other hand, the results on loan projects are consistent with the study of Mollick (2014) who identified that the number of project to be one of the factor driving the success of internet finance companies. In this study, the project-level factors used are average loan periods and number of loan projects. The project-level factors assume that investors are given various projects to choose based on their investment preference. The number of projects comes from the combination of period and interest rate. As internet finance companies provide more projects, investors will be attracted by the more choices and generate higher total transactions.. Our results on firm strategies adopted by the internet finance companies in this study are consistent with earlier studies which found that total transactions positively related to the differentiation strategy but negatively related to the cost-leadership strategy, i.e. interest rate (Fernando, Schneible, \& Tripathy, 2016).

\section{CONCLUSION}

China has long been recognized as the country with a weak financial system due to its long term poor institutional system. In recent years, however, new players have joined the Chinese financial market, gradually transforming the traditional borrowing and lending system of the country. With the proliferation of the information and communications technology ecosystem, the Chinese financial industry has undergone rapid growth, and the trend of internet finance has just emerged to challenge the offline financial system of the country (Shim \& Shin, 2016). Meanwhile, SMEs play an important role in the development of a nation's economic growth and the scenario in China is no different. To accelerate the roles of the SMEs in China, financing must be made easier and more convenient for these companies. Since China's conventional banking industry has not been very supportive of SMEs, there has been a gap in how SMEs conduct businesses. The lack of support from conventional banks hinder SMEs from access to adequate financial to develop their business further. 
Therefore, the emergence of internet finance would help SMEs to resolve their financial woes and further encourage the development of SMEs thereby contributing to China's economic growth. This study provide evidence that the two key determinants of internet finance companies performance are average loan periods and loan projects. Hence, internet finance companies could focus on these determinants in order to enhance their performance. However, our study revealed that interest rate has a negative effect to performance of internet finance companies. This implies that investors do not give return consideration when make investment decisions. The negative result from this study on interest rate relate to internet finance companies performance reflect the risk concern of the investors. With internet finance fast gaining popularity, there may also be some problems which can cause huge losses for borrowers and lenders. Undoubtedly, platforms which have good performance will attract larger numbers of users thereby generating large volumes of transactions. Nonetheless, such types of good performance do not mean that there is an absence in risks for investors. This is because those factors causing internet finance platforms to default are still unclear. More studies to be conducted to address the inadequacy. The risk may be the other reason that investors care when participate in internet finance in China and the risk factor could be considered in the further research.

As with other research, this study has several limitations. First, this study focused only on 330 internet finance companies compared with total 1863 internet finance companies in the market of China. The results from these 330 internet finance companies may not reflect the whole situation of internet finance companies in China. Second, this study only uses one point data, however, we argue that our results have demonstrate the impact of competitive strategies employed by internet finance companies on their performance. Thirdly, only three main factors investigated from the operation information of internet finance companies. Hence, we suggest that future studies should also include more factors and data collections over a long-term period in order to provide a comprehensive analysis on factors influencing firm performance of internet finance companies. Future studies could also explore the reasons that leading negative interest rate to firm performance of internet finance companies.

\section{REFERENCE}

[1] Ayyagari, M., Beck, T., \& Demirguc-Kunt, A. (2007). Small and medium enterprises across the globe. Small Business Economics, 29(4), 415-434. doi:10.1007/s11187-006-9002-5

[2] Bhagat, S., Carey, D. C., \& Elson, C. M. (1998). Director ownership, corporate performance, and management turnover. SSRN Electronic Journal. doi:10.2139/ssrn.134488

[3] Bodenhorn, H. (2003). Short-term loans and long-term relationships: relationship lending in early America. Journal of Money, Credit and Banking, v35(4,Aug), 485-505. doi:10.3386/h0137

[4] Bruton, G., Khavul, S., Siegel, D., \& Wright, M. (2015). New financial alternatives in seeding entrepreneurship: microfinance, crowdfunding, and peer-to-peer innovations. Entrepreneurship Theory and Practice, 39(1), 9-26. doi:10.1111/etap.12143

[5] Burgstaller, J., \& Wagner, E. (2015). How do family ownership and founder management affect capital structure decisions and adjustment of
SMEs? The Journal of Risk Finance, 16(1), 73-101. doi:10.1108/jrf-06-2014-0091

[6] Cai, S., Lin, X., Xu, D., \& Fu, X. (2016). Judging online peer-to-peer lending behavior: a comparison of first-time and repeated borrowing requests. Information \& Management, 53(7), 857-867. doi:10.1016/j.im.2016.07.006

[7] D'Imperio, R. (2012). Growing the global economy through SMEs. Retrieved from http://www.edinburgh-group.org/media/2776/edinburgh_group_researc h_-_growing_the_global_economy_through_smes.pdf

[8] Dong, W. (2014). Hulianwang jinrong mianlin sidafengxian China Youth Daily.

[9] Elliott, D. J., \& Yan, K. ( 2013). The Chinese financial system an introduction and overview. Retrieved from https://www.brookings.edu/wp-content/uploads/2016/06/chinese-financ ial-system-elliott-yan.pdf

[10] Falkner, E. M., \& Hiebl, M. R. W. (2015). Risk management in SMEs: a systematic review of available evidence. The Journal of Risk Finance, 16(2), 122-144. doi:10.1108/jrf-06-2014-0079

[11] Fernando, G. D., Schneible, R. A., \& Tripathy, A. (2016). Firm strategy and market reaction to earnings. Advances in Accounting, 33, 20-34. doi:10.1016/j.adiac.2016.04.006

[12] Ferrando, A., \& Mulier, K. (2015). Firms' financing constraints: do perceptions match the actual situation? The Economic and Social Review, 46(1, Spring).

[13] Gonzalez, L., \& McAleer, K. (2014). Determinants of success in online social lending: a peak at US prosper \& UK zopa. SSRN Electronic Journal. doi:10.2139/ssrn.2442442

[14] Honohan, P., \& King, M. (2009). Cause and effect of financial access: cross-country evidence from the finscope surveys. Paper presented at the Measurement, Promotion, and Impact of Access to Financial Services, Washington DC.

[15] Ittner, C. D., \& Larcker, D. F. (1998). Are nonfinancial measures leading indicators of financial performance? an analysis of customer satisfaction. Journal of Accounting Research, 36. doi:10.2307/2491304

[16] iTurst. (2017). 2017 Annual report of China internet finance. Retrieved from http://www.itrust.org.cn/

[17] Jing, M. (2014). Alibaba, lenders team up for SME financing. Business

[18] Kavale, S., Mugambi, F., \& Namusonge, G. (2016). The effects of product differentiation strategy on corporate growth in selected microfinance institutions in Kenya. International Journal for Research in Business, Management and Accounting, 2(6).

[19] Klafft, M. (2008). Online peer-to-peer lending: a lenders' perspective. SSRN Electronic Journal. doi:10.2139/ssrn.1352352

[20] Kredite, P. P. ( 2007). Rebellion der anleger im Prosper forum.

[21] Kshetri, N. (2016). Big data's role in expanding access to financial services in China. International Journal of Information Management, 36(3), 297-308. doi:10.1016/j.ijinfomgt.2015.11.014

[22] Lavia López, O., \& Hiebl, M. R. W. (2015). Management accounting in small and medium-sized enterprises: current knowledge and avenues for further research. Journal of Management Accounting Research, 27(1), 81-119. doi:10.2308/jmar-50915

[23] Lin, S. (2007). SMEs credit risk modelling for internal rating based approach in banking implementation of Basel II requirement. The University of Edinburgh,

[24] Michels, J. (2012). Do unverifiable disclosures matter? evidence from peer-to-peer lending. The Accounting Review, 87(4), 1385-1413. doi:10.2308/accr-50159

[25] Milne, A., \& Parboteeah, P. (2016). The business models and economics of peer-to-peer lending.

[26] Mollick, E. (2014). The dynamics of crowdfunding: An exploratory study. Journal of Business Venturing, 29(1), 1-16. doi:10.1016/j.jbusvent.2013.06.005

[27] Moreira, D. F. (2016). The microeconomic impact on growth of SMEs when the access to finance widens: evidence from internet $\&$ high-tech industry. Procedia - Social and Behavioral Sciences, 220, 278-287. doi:10.1016/j.sbspro.2016.05.500

[28] OECD. (2016). Financing SMEs and entrepreneurs 2016.

[29] Ortega, M. J. R. (2010). Competitive strategies and firm performance: Technological capabilities' moderating roles. Journal of Business Research, 63(12), 1273-1281. doi:10.1016/j.jbusres.2009.09.007

[30] Porter, M. (1980). Competitive strategy: techniques for analyzing industries and competitors: Free Press.

[31] Porter, M. (1985). The competitive advantage: creating and sustaining superior performance: NY: Free Press.

[32] Prelipcean, G., \& Boscoianu, M. (2014). A hybrid framework for SME financing based on the mix between governmental support and the use of a specialized investment fund in the actual context of a slow recovery after crises and turbulences. Procedia 
Economics and Finance, 15, 738-745. doi:10.1016/s2212-5671(14)00445-6

[33] Rose, S. (2007). The Prosper lender rebellion, and the US credit/borrowing black hole. P2P foundation.

[34] Serrano-Cinca, C., Gutierrez-Nieto, B., \& Lopez-Palacios, L. (2015). Determinants of default in P2P lending. PLoS One, 10(10), e0139427. doi:10.1371/journal.pone. 0139427

[35] Shammot. (2011). Quality management practices and their impact on organizational performance, and customer behavior. European Journal of Economics, Finance and Administrative Sciences, 34.

[36] Shih, K. (2018). China Fintech Sector. Retrieved from DBS Group Research

[37] Shim, Y., \& Shin, D.-H. (2016). Analyzing China's fintech industry from the perspective of actor-network theory. Telecommunications Policy, 40(2-3), 168-181. doi:10.1016/j.telpol.2015.11.005

[38] Traci L. Mach, C. M. C., and Cailin R. Slattery. (2014). Peer-to-peer lending to small businesses. Finance and Economics Discussion Series Divisions of Research \& Statistics and Monetary Affairs Federal Reserve Board, Washington, D.C

[39] Wahid, F., \& Rehman, Z. U. (2014). Share of the Informal Loans in Total Borrowing in Pakistan: A Case Study of District Peshawar. Journal of Managerial Sciences, 8(1), 103-113.

[40] Wildau, G. (2015). Alibaba's finance arm launches credit scoring service.

[41] Xinhua. (2017). Chinese central bank to include internet finance into macro prudential assessment. Retrieved from http://www.chinadaily.com.cn/business/2017-08/07/content_30350764 .htm

[42] Xu, J. (2017). China's internet finance: a critical review. China \& World Economy, 25(4), 78-92. doi:10.1111/cwe.12207

[43] Yamane, T. (1973). Statistics. an introductory analysis (Third edition ed.): Harper \& Row.

[44] Yin, W., \& Liu, X. (2016). Bank versus nonbank financial institution lending behaviour: indictors of firm size, risk or ownership? Applied $\begin{array}{llll}\text { Economics } & \text { Letters, } & \text { 24(18), } & \text { 1285-1288. }\end{array}$ doi:10.1080/13504851.2016.1273473

[45] Yum, H., Lee, B., \& Chae, M. (2012). From the wisdom of crowds to my own judgment in microfinance through online peer-to-peer lending platforms. Electronic Commerce Research and Applications, 11(5), 469-483. doi:10.1016/j.elerap.2012.05.003

[46] Zhu, J., \& Huang, Z. (2014). Banks' micro enterprises loan credit risk decision-making model innovation in the era of big data and internet finance. Journal of Management and Strategy, 5(2). doi:10.5430/jms.v5n2p63

[47] Zott, C., \& Amit, R. (2010). Business model design: an activity system perspective. Long Range Planning, 43(2-3), 216-226. doi:10.1016/j.lrp.2009.07.004

i OECD (2016)

ii $\mathrm{OECD}(2016)$

iii 2017 Annual report of China iTrust Internet Credit Certification

\section{AUTHORS PROFILE}

My name is Tian Zhongkai, working with PUTRA Business School, Universiti Putra Malaysia, 43400, Serdang, Selangor, Malaysia. I like to learn new things and techniques in business.

I am Ahmad Fahmi Sheikh Hassan, affiliated with Department of Accounting and Finance, Faculty of Economics and Management, Universiti Putra Malaysia 